\title{
Climate change impact on China food security in 2050
}

\author{
Liming Ye • Wei Xiong • Zhengguo Li • Peng Yang • \\ Wenbin Wu • Guixia Yang • Yijiang Fu • Jinqiu Zou • \\ Zhongxin Chen • Eric Van Ranst • Huajun Tang
}

Accepted: 21 June 2012 / Published online: 11 July 2012

(C) The Author(s) 2012. This article is published with open access at Springerlink.com

\begin{abstract}
Climate change is now affecting global agriculture and food production worldwide. Nonetheless the direct link between climate change and food security at the national scale is poorly understood. Here we simulated the effect of climate change on food security in China using the CERES crop models and the IPCC SRES A2 and B2 scenarios including $\mathrm{CO} 2$ fertilization effect. Models took into account population size, urbanization rate, cropland area, cropping intensity and technology development. Our results predict that food crop yield will increase $+3-11 \%$ under A2 scenario and $+4 \%$ under B2 scenario during 2030-2050, despite disparities among individual crops. As a consequence China will be able to achieve a production of 572 and $615 \mathrm{MT}$ in 2030, then 635 and $646 \mathrm{MT}$ in 2050 under A2 and B2 scenarios, respectively. In 2030 the food security index (FSI) will drop from $+24 \%$ in 2009 to $-4.5 \%$ and $+10.2 \%$ under A2 and B2 scenarios, respectively. In 2050,
\end{abstract}

L. Ye $(\bowtie) \cdot \mathrm{Z}$. Li $\cdot$ P. Yang $\cdot \mathrm{W}$. Wu $\cdot$ G. Yang $\cdot$ J. Zou $\cdot$ Z. Chen $\cdot$ H. Tang

MOA Key Laboratory of Agri-Informatics, Institute of

Agricultural Resources and Regional Planning, Chinese Academy of Agricultural Sciences,

12 Zhongguancun South Street,

100081 Beijing, China

e-mail: limingye@caas.net.cn

L. Ye $\cdot$ E. Van Ranst

Department of Geology and Soil Science, Ghent University, 9000 Gent, Belgium

\section{W. Xiong}

Institute of Environment and Sustainable Development in Agriculture, Chinese Academy of Agricultural Sciences, 100081 Beijing, China

Y. Fu

School of Continuing Education, Renmin University of China, 100872 Beijing, China however, the FSI is predicted to increase to $+7.1 \%$ and $+20.0 \%$ under A2 and B2 scenarios, respectively, but this increase will be achieved only with the projected decrease of Chinese population. We conclude that 1) the proposed food security index is a simple yet powerful tool for food security analysis; (2) yield growth rate is a much better indicator of food security than yield per se; and (3) climate change only has a moderate positive effect on food security as compared to other factors such as cropland area, population growth, socio-economic pathway and technology development. Relevant policy options and research topics are suggested accordingly.

Keywords Food security $\cdot$ Climate change $\cdot$ Crop modeling Crop yield $\cdot$ Scenario $\cdot$ Food production $\cdot$ Policy $\cdot$ China

\section{Introduction}

Global surface temperature has increased $0.8{ }^{\circ} \mathrm{C}$ during the past century; four thirds of this increase occurred in the last three decades (Hansen et al. 2006). The acceleration in global warming and its associated changes in precipitation have already affected the ecosystems, biodiversity and human systems on Earth (Kotir 2011). Among the many impacts of climate change, the risk to agriculture is considered one of the most significant. Climate change affects agriculture and the food production system in many ways (Godfray et al. 2011). Crop production is affected by climatic variables such as rising temperatures, changing precipitation regimes and increased atmospheric $\mathrm{CO}_{2}$ levels; it is also affected by biological variables such as the lengths of the crop growth periods and the crop cycle. A longer life cycle was one of the most widely observed biological changes in the response of crops to climatic warming across the Northern Hemisphere during the twentieth century 
(Steltzer and Post 2009). Overall, the yields of wheat and maize have responded negatively to the recent warming since the 1980 s at the global scale, although the yield response signals of other crops (e.g., rice) have still been unclear (Lobell and Field 2007). Global food production may need to increase by as much as $70 \%$ in 2050 for a world of 9 billion people (Schmidhuber and Tubiello 2007). It will be a major challenge to fulfill this global food security goal under climate change. This is especially true for China as the world's most populous country and the third largest in land area.

China is among the most affected countries by climate change (Turral et al. 2011). Although much research in China has focused on the impact of climate change on food production (Lin et al. 2005; Lobell et al. 2008; Piao et al. 2010), systematic studies that directly link climate change and food security are still lacking, especially at the national scale. Essentially, food security assessment needs to consider parameters involving not only food production but also food consumption, resulting in added complexity hence difficulty in data collection and model building (Schmidhuber and Tubiello 2007). The objectives of this paper are to: (1) simulate the yield of major food crops in China under the IPCC SRES A2 and B2 scenarios in 2030/2050; (2) assess the impact of climate change on food security in China, involving scenarios of population size, urbanization rate, cropland area, cropping intensity, technology development, etc.; and (3) formulate policy options to ensure China's food security under climate change in 2030/2050.

\section{Materials and methods}

\subsection{Research framework}

A five-step approach has been adopted in this research. First, climatic, crop, soil, management, and socioeconomic data were collected, manipulated, and used to simulate the yields of food crops. Second, the simulated yields were compared to the observed yields in order to validate the simulation process. Third, the food production capacities in 2030 and 2050 were estimated based on the scenarios of population growth, urbanization rate, cropland area, cropping intensity, new crop varieties, and management improvements, which were all designed in line with the socio-economic development pathways associated with climate change scenarios. Fourth, a food security index (FSI) was computed based on the analysis of the supplydemand relationship of food produced from agricultural crops. Finally, the effect of climate change on the FSI was quantitatively evaluated, and policy options toward longterm food security in China were formulated (Fig. 1).

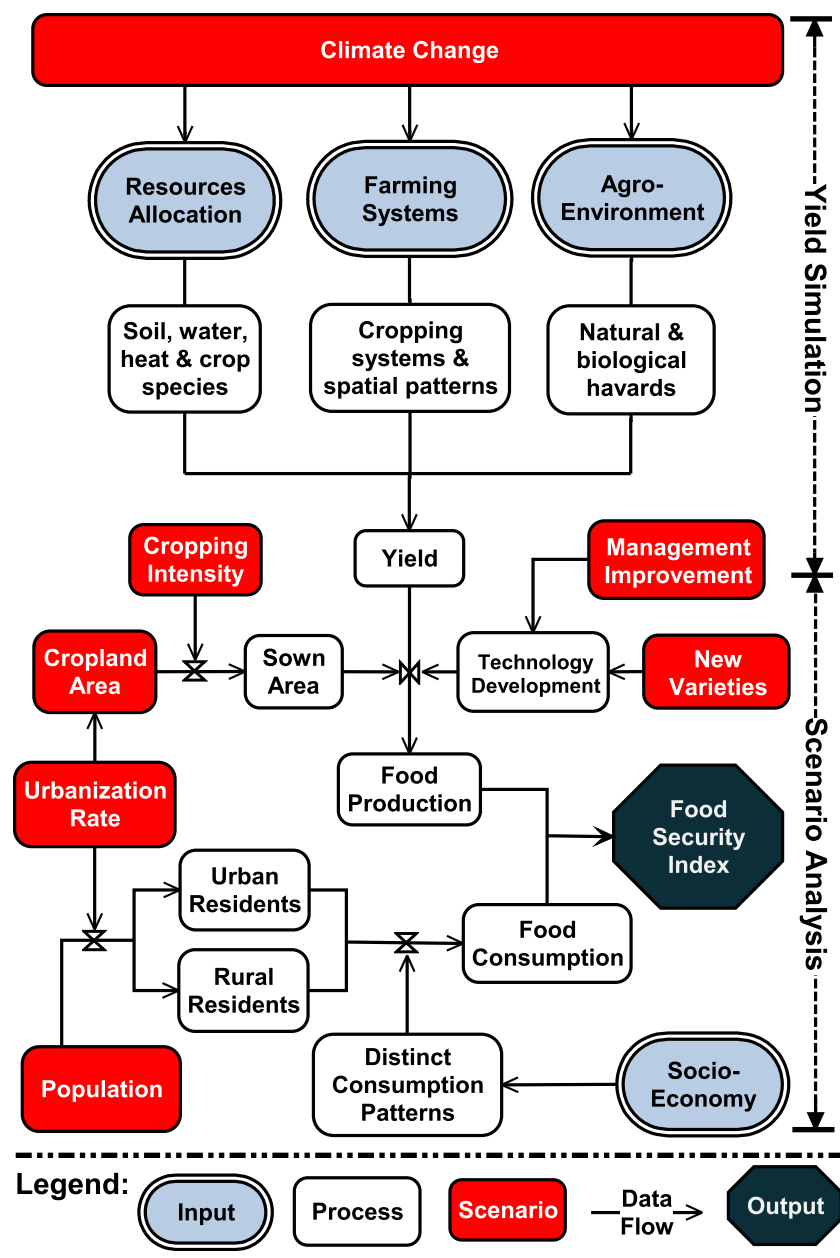

Fig. 1 The flow chart of the research framework. Food security assessment is conducted from a supply-demand point of view involving a series of scenarios

\subsection{Data manipulation}

To facilitate the simulation of the yields of major food crops including rice (Oryza sativa L.), wheat (Triticum aestivum L.), and maize (Zea mays L.), the study area was divided into grid cells of 404 rows by 482 columns, each of $100 \mathrm{~km}^{2}$. The cell number was used as an index to store input parameters in a relational database. Daily climatic variables of maximum and minimum temperature, precipitation, and sunshine duration from 680 stations were provided by the Chinese Meteorological Data Center over the period 1981-2000. These stations form a spatially representative climatic network over croplands in China (Fig. 2a). Daily solar radiation was derived from a linear relationship with $\mathrm{n} / \mathrm{N}$ (actual to maximum ratio of daily hours of sunshine) as given by Pohlert (2004). Each grid cell was associated with the nearest meteorological station. The soil parameters (clay-silt-sand contents, bulk density, $\mathrm{pH}$, and organic carbon content) were obtained from the National Soil Survey Office; soil moistures at field capacity and 
$1961-90 \sim 2011-20$
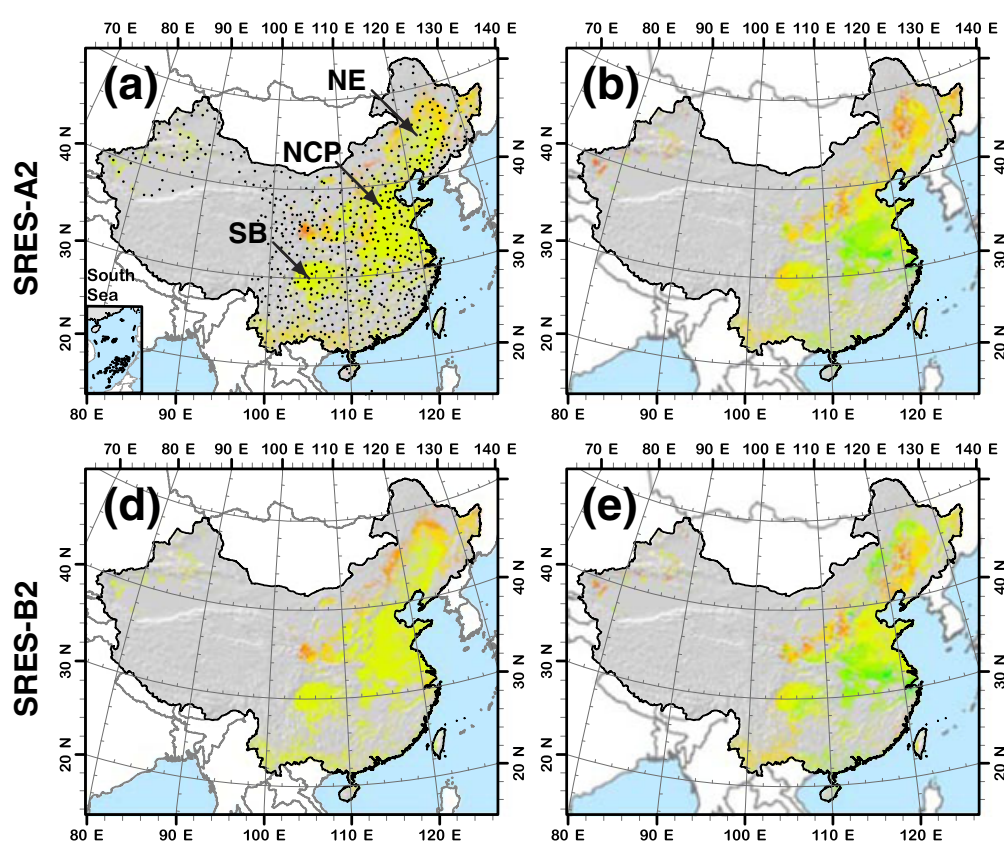

2011-20 2021-30

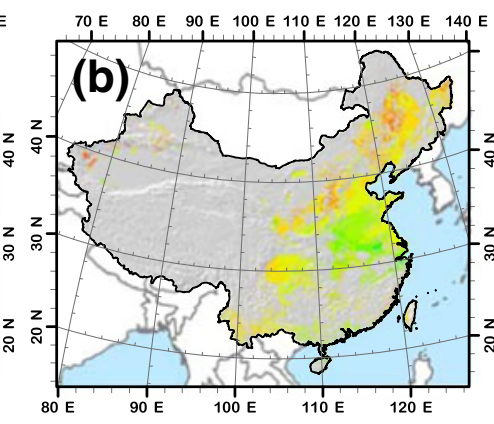

T0E 80 E 90 E 100 E 110 E 120 E 130 E 140 E

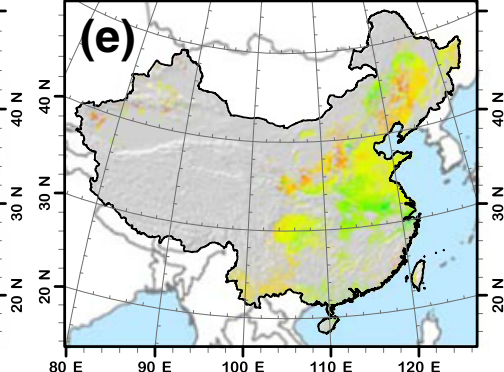

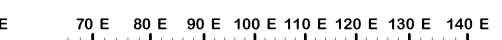

2021-30 2031-40
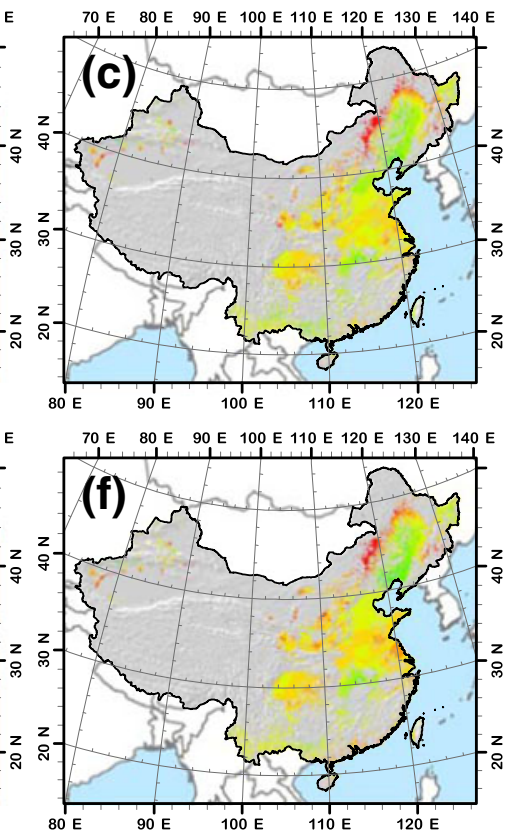

Yield Growth Rate

$\left(\% \mathrm{yr}^{-1}\right)$
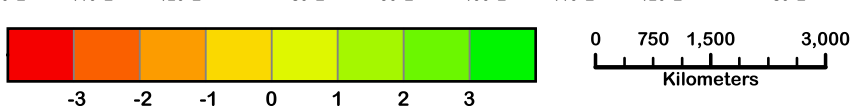

- Climatic station

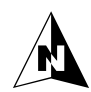

Fig. 2 Annual yield growth rate of maize in China under the SRES A2 and B2 scenarios, calculated from the average simulated yields between the periods of 1961-1990 and 2011-2020 (a, d), between 20112020 and 2021-2030 (b, e), and between 2021-2030 and 2031-2040

(c, f). The maize cropping area is extracted from the MIRCA2000 dataset (Portmann et al. 2010) and upscaled to the spatial scale of $10 \mathrm{~km}$. Black dots (a) represent climatic stations. NE Northeast, NCP North China Plain, $S B$ Sichuan Basin

wilting point were derived using pedo-transfer functions (Pawls et al. 1982). A GIS procedure was followed to rasterize the soil mapping units into $10 \times 10 \mathrm{~km}$ grid cells (Knox et al. 2000). Crop (cultivar, sowing date, length of crop cycle and phenological subdivisions, leaf area index at max. growth rate, harvest index, and rooting depth) and management parameters (sowing density, row width, transplanting date, fertilizer application date and quantity, irrigation date, and volume) were collected per experimental site (Xiong et al. 2008a) and assigned to the grid cells using the same approach as for the meteorological parameters. In total 522 yield trials from 119 experimental stations were used for, e.g., rice (Xiong et al. 2008a).

\subsection{Yield simulation}

The yields of rice, wheat, and maize were simulated per grid cell of cropland using the CERES-Rice, Wheat and Maize model, respectively, with the $\mathrm{CO} 2$ fertilization effect included (Lin et al. 2005; Lobell and Field 2008). The spatial distribution of cropland (Fig. 2) was assessed based on the MIRCA2000 dataset (Portmann et al. 2010). The CERES models are dynamic process-based mechanistic models that simulate daily phenological development and growth in response to environmental (climate and soil) and management factors (crop variety, planting conditions, $\mathrm{N}$ fertilization, irrigation, etc.). The CERES models have been validated in a wide variety of environment, ranging from temperate to tropical, across the world (Jones et al. 2003).

The models run for three times to simulate the irrigated and the rainfed yields at the grid scale. The first simulation run was performed for the calibration period of 1981-2000; the second run was performed for the reference period of 1961-1990, while the third run was performed for the projection period of 2011-2040. Climatic data of the reference and the projection periods was derived and downscaled from the PRECIS, or Providing Regional Climates for Impact Studies (Xu et al. 2006), model for China. The baseline scenario used the PRECIS simulated daily weather data for 1961-1990 with the $\mathrm{CO}_{2}$ concentration set at $\sim 330$ ppm. Two climate change scenarios, namely A2 and B2, for 2011-2040 were also generated. The IPCC SRES A2 scenario describes a very heterogeneous world of high population growth, slow economic development, and strong regional cultural identities, while the $\mathrm{B} 2$ scenario reflects a heterogeneous world with diverse technological change, low population growth and emphasis on local solutions to economic, social, and environmental sustainability problems. The SRES A2 and B2 scenarios were selected to 
represent two contrasting development pathways, pessimistic versus optimistic, for China, respectively.

The area-weighted average crop yield $Y\left(\mathrm{t} \mathrm{ha}^{-1}\right)$ is calculated at the grid scale from the simulated rainfed $\left(Y_{\text {rain }}\right)$ and irrigated ( $\left.Y_{\text {irri }}\right)$ yields (Ye et al. 2008):

$Y=p \cdot Y_{\text {irri }}+(1-p) \cdot Y_{\text {rain }}$

where $p \in[0,1]$ is the irrigation probability, $p=$ $S_{\text {irri }} /\left(S_{\text {irri }}+S_{\text {rain }}\right)$ with $S_{\text {irri }}$ and $S_{\text {rain }}$ being the irrigated and rainfed areas, respectively. The irrigated and rainfed crop areas were evaluated based on the MIRCA2000 dataset (Portmann et al. 2010).

\subsection{Scenario building}

The socio-economic and agronomic scenarios of population size, urbanization rate, cropland area, cropping intensity, and technology development (including new crop varieties and management improvement) were designed in line with the pessimistic versus optimistic development pathways represented by the SRES A2 and B2 emission scenarios, respectively. The settings of these scenarios are given in Table 1.

The logistic growth model was employed on the historical Chinese population data (NBSC 2010) to quantify the future trends of population growth. The UNFPA (2010) projected size of 1.42 billion in 2050 and plateau time in 2025 set the key parameters of the low growth variant of the population scenario, corresponding to the SRES B2 emission scenario. The urbanization scenario was based on the historical trend of urban population growth of $1 \%$ year $^{-1}$ observed during 1978-2009 and on China's national development strategy (Change and Brada 2006). Since the year
2000, cropland in China has been lost at a rate of 1.45 million hectares per year. Urbanization was known as the major driver of it. The future evolution of cropland area was evaluated by coupling the loss of cropland with urbanization rate, using a linear regression model (Ye and Van Ranst 2009). Cropping intensity, expressed in terms of the multicropping index (MCI) or the ratio between total sown area and the cropland area, increased steadily at a rate of $0.9 \%$ year ${ }^{-1}$ during the past 20 years. Although double cropping or even triple cropping is a common practice in southern China, the national MCI average in 2009 was only $130 \%$. A study conducted by the National Office of Agricultural Regional Planning (NOARP 1997) suggested that the average MCI in China could reach $170 \%$, with a theoretical potential of $190 \%$.

Two forms of technology development were considered in scenario building. One was the breakthroughs in crop breeding technologies (Tester and Langridge 2010), which produces higher-yielding varieties, and the other was management improvements in terms of, e.g., raised efficiency of fertilizer use and associated field management techniques. Field trials from China indicated that use of inorganic fertilizer increased the yield of major food crops by $47.8 \%$ (Jin 2011), although over fertilization also caused a number of eco-environmental problems such as GHG emission (Tester and Langridge 2010) and soil acidification (Guo et al. 2010). With bio-technology breakthroughs, gradual adoption of higher-yielding varieties is considered capable of raising crop yields at an average rate of $0.8 \%$ year $^{-1}$ before 2030 and $0.5 \%$ year $^{-1}$ thereafter (Zhao et al. 2008). Based on statistical modeling using data from 5 Chinese provinces during 1988-2007, Li et al. (2011) found that $0.7 \%$ of the yield growth rate can be attributed to management improvements. These yield enhancement technologies are fully implementable under SRES B2, due to its intrinsic capacity
Table 1 Settings of the socioeconomic and agronomic scenarios associated with the IPCC SRES A2 and B2 emission scenarios, including population size, urbanization rate, cropland area, multi-cropping index (MCI), and technology development in terms of yield enhancements resulting from crop variety and management improvements

$N A$ not applicable

\begin{tabular}{lcccccc}
\hline Year & $\begin{array}{l}\text { Population } \\
(\text { million })\end{array}$ & $\begin{array}{l}\text { Urbanization } \\
(\%)\end{array}$ & $\begin{array}{l}\text { Cropland } \\
(\text { million ha. })\end{array}$ & $\begin{array}{l}\text { MCI } \\
(\%)\end{array}$ & $\begin{array}{l}\text { Variety } \\
\left(\% \text { year }^{-1}\right)\end{array}$ & $\begin{array}{l}\text { Management } \\
\left(\% \text { year }^{-1}\right)\end{array}$ \\
\hline $\begin{array}{l}\text { Baseline } \\
2009\end{array}$ & 1,334 & 46.3 & 121.7 & 130 & NA & NA \\
SRES A2 & (Pessimistic) & & & & & \\
2020 & 1,505 & 58.2 & 118.0 & 134 & 0.40 & 0.35 \\
2030 & 1,577 & 62.9 & 115.0 & 139 & 0.40 & 0.35 \\
2040 & 1,590 & 65.8 & 113.3 & 144 & 0.25 & 0.20 \\
2050 & 1,560 & 68.6 & 111.6 & 150 & 0.25 & 0.20 \\
SRES B2 & $($ Optimistic $)$ & & & & & 0.70 \\
2020 & 1,455 & 64.6 & 116.0 & 137 & 0.80 & 0.70 \\
2030 & 1,469 & 72.6 & 111.0 & 148 & 0.80 & 0.40 \\
2040 & 1,451 & 77.6 & 108.0 & 158 & 0.50 & 0.40 \\
2050 & 1,417 & 82.6 & 105.0 & 169 & 0.50 & \\
\hline
\end{tabular}


to accommodate technological changes, and only partially implementable under A2 (Table 1).

\subsection{Food security assessment}

Food security was defined by the World Food Summit in 1996 as a "situation that exists when all people, at all times, have physical, social and economic access to sufficient, safe and nutritious food that meets their dietary needs and preferences for an active and healthy life." Since then, numerous measures have been used to quantify the overall status and regional discrepancies in global food security (or insecurity), including the FAO indicators of undernourishment (Schmidhuber and Tubiello 2007). However, none of these have been widely accepted for the populous Asian countries. As in other Asian countries, food security in China almost exclusively means food self-sufficiency or even grain self-sufficiency (Jiang 2008). The grain selfsufficiency level of $95 \%$ has recently been adopted as a strategic goal for maintaining food security in China.

It is important to note that: (a) China's population is too large to rely on the world food market for its food supply, (b) the swift and fair distribution of large quantities of imported food is a major challenge given the scale of China, and (c) food is a special good and its selfsufficiency has domestic political and economic significance (Jiang 2008). Therefore, the relative food surplus is defined in this paper as the food security index, or FSI, in an attempt to measure the general status of food security in China:

$F S I=\frac{s / g-d}{d} \cdot 100$

where $s$ is the per capita food supply, $d$ is the per capita food demand, and $g$ is the expected food self-sufficiency level $(g=0.95)$.

\section{Results and discussion}

\subsection{Model validation}

The performance of the CERES crop models in predicting crop yields in space and time has primary importance in long-term decision making. Thus, a lot of efforts have been made to adequately calibrate the CERES models for use in regional yield simulations in China and to thoroughly evaluate their performances in regional climate impact studies, as separately reported (Xiong et al. 2008a; 2008b). Year-byyear comparisons between the simulated yields (19812000) and the observed yields, which were collected and detrended (Easterling et al. 1996) from the agricultural meteorological experimental station network in China, showed that the simulated yields were in good agreement with the observed yields. In the case of maize (Xiong et al. 2007), for instance, yield records from four experimental stations representing major maize growing regions across China were used for comparison; they are Changjizhou $\left(44^{\circ} \mathrm{N}\right.$, $\left.87.43^{\circ} \mathrm{E}\right)$ in Xinjiang province, Zhengzhou $\left(34.72^{\circ} \mathrm{N}\right.$, $\left.113.65^{\circ} \mathrm{E}\right)$ in Henan province, Guangyuan $\left(32.43^{\circ} \mathrm{N}\right.$, $\left.105.85^{\circ} \mathrm{E}\right)$ in Sichuan province, and Harbin $\left(45.75^{\circ} \mathrm{N}\right.$, $126.77^{\circ} \mathrm{E}$ ) in Heilongjiang province. The results showed that $96 \%$ of the variations in the observed yields was reproduced by the simulated yields, or $R^{2}=0.96(p<0.01)$. The spatial pattern of the variability in observed yields was reasonably well captured by the model-simulated yields. A case study in Northeast China's Jilin Province, in which the county-level census maize yields from 1981 to 2000 were first downscaled to the grid level and then compared to the simulated yields, showed that the simulated and the census yields were correlated across all grids $\left(R^{2}=0.24, p<0.05\right)$, and the simulated annual yields correlated to observed annual yields in $69 \%$ of the grids at the confidence level of $95 \%$. Overall, these results are encouraging in regional yield simulation and provide reasonable confidence in the simulation results in space and time.

\subsection{Yield growth rate under climate change}

The rainfed and irrigated yields of major food crops were simulated annually at the grid scale during the reference period of 1961-1990 and during the projection period of 2011-2040. The simulated rainfed and irrigated yields were combined to derive the yield of a particular crop (e.g., maize) using Eq. 1. The multi-year mean of the simulated yield was calculated for the reference period and for each decade of the projection period. The compound annual yield growth rate (\%), $r$, was computed from the mean yields using the following equations:

$Y_{2}=Y_{1} \cdot(1+r / 100)^{n}$

thus

$r=100 \cdot\left[\exp \left(\frac{1}{n} \log \left(Y_{2} / Y_{1}\right)\right)-1\right]$

where $Y_{1}$ is the average crop yield during period $1, Y_{2}$ is the average yield during period 2 , and $n$ is the distance between period 1 and period 2, counted in number of years from the middle year of period 1 to the middle year of period 2. For example, $n=40$ between the periods 1961-1990 (centered at 1975) and 2011-2020 (center at 2015). As an example, compound annual yield growth rate of maize, evaluated either between the reference and the projection periods or at the decadal intervals within the projection period, under 
the SRES A2 and B2 scenarios are shown in Fig. 2. The crop-specific yield growth rates, aggregated at the national scale, are summarized in Table 2.

The maize yield in Northeast China, for example, is projected to respond negatively to climate change during the 2015 (as the mid-point of the 2011-2020 decade) to 2025 (mid-point 2021-2030) period under the SRES A2 scenario, as shown by the dominating brownish colors in Fig. 2b. In another major region in food production in China, the Sichuan Basin, the impact is projected to be marginal to negligible. Unsurprisingly, similar spatial disparities are also observed for other periods of time (Fig. 2c) or under other scenarios (Fig. 2e, f). Overall, the maize yield is projected to increase at $0.2-0.3 \%$ annually at the national scale during 2011-2040 under A2. This translates into a yield change of $+10 \%$ in 2040 over the 1961-1990 average. Under the B2 scenario, the maize yield is projected to first increase at $0.5 \%$ annually during 2011-2030 and then decrease slightly at an annual rate of $-0.05 \%$ during 2031-2040. Temporal disparities in yield growth rates of wheat and rice under climate change are also observed (Table 2).

Our results show largely positive (or less negative) effects of climate change on crop yield in China, contrasting with earlier estimates in many cases. Using yield transfer functions, Parry et al. (2004), e.g., demonstrated that climate change would decrease cereal yield in China by $2.5-10 \%$ and $2.5-5 \%$ in 2020 under A2 and B2 scenarios, respectively, and by $5-10 \%$ in 2050 under either A2 or B2. A recent assessment using the EPIC model (Wu et al. 2011) also revealed negative impacts of climate change on crop yield in China, especially in the most important food production region of North China Plain. One fundamental difference between this research and those mentioned above is that $\mathrm{CO}_{2}$ fertilization (Gosling et al. 2011; Lobell and Field 2008) was intentionally included in this simulation, while $\mathrm{CO}_{2}$ fertilization was excluded from others such as those of Parry et al. (2004) and Wu et al. (2011). The rationale to consider $\mathrm{CO}_{2}$ fertilization is that the rise of atmospheric $\mathrm{CO}_{2}$ concentration has already been an observed fact and it will continue to rise in the foreseeable future, despite uncertainties about the magnitude of this rise (Lin et al. 2005; Long et al. 2006). Elevated $\mathrm{CO}_{2}$ concentrations stimulate photosynthesis, by a margin of $\sim 0.08 \%$ for rice and wheat and $\sim 0.05 \%$ for maize per $1 \mathrm{ppm}$ increase, leading to increased plant productivity and modified water and nutrient cycles. Past studies suggested that crop yield tends to increase under higher $\mathrm{CO}_{2}$ concentrations (Tubiello et al. 2007). Compared with the current atmospheric $\mathrm{CO}_{2}$ concentrations of $\sim 380 \mathrm{ppm}$, crop yields increase at $550 \mathrm{ppm} \mathrm{CO} \mathrm{CO}_{2}$ in the range of $10-20 \%$ for $\mathrm{C}_{3}$ crops (e.g., rice and wheat) and $0-10 \%$ for $\mathrm{C}_{4}$ crops (e.g., maize). The magnitude of the positive yield effects found here (Table 3, no technology) fell well in this range. Although the robustness of $\mathrm{CO}_{2}$ fertilization is being debated (Gosling et al. 2011; Long 2012), its yield effect has been confirmed by a variety of field experiments such as the free-air carbon dioxide enrichment (FACE) experiment.

The temporal variabilities of the simulated yield effects (Table 2, Fig. 2) at the decadal time scale can be explained as large-scale responses of crops to future temperature and precipitation trends as governed by climate scenarios used (Xiong et al. 2007). Historically, spatial variations of precipitation in major agricultural regions in China showed a 10-year north-south oscillation between the Yellow River Basin and the Yangtze River Basin regions. It has been observed that in the years when the Yellow River Basin receives more precipitation than the Yangtze River Basin, the Yangtze River Bain usually receives higher radiation due to lower chance of cloud cover. During these years, rice in the Yangtze River Basin could benefit from less precipitation plus higher radiation, while wheat and maize in the Yellow River Basin could benefit from more precipitation. On the other hand, in the years when the Yangtze River Basin receives more precipitation, the Yellow River Basin usually experiences higher frequency of draughts. The climatic conditions in these years are undesirable for both rice (higher precipitation, lower radiation) in the Yangtze River Basin and wheat and maize (lower precipitation, higher radiation) in the Yellow River Basin, as observed during late 1990s. This tempo-spatial pattern was reproduced by most regional climate models (RCMs) in China such as PRECIS (Xu et al. 2006) which was used to generate climate scenarios in this research. The decadal temporal pattern of yield variability described here is usually more obvious under scenarios accommodating more extreme events (e.g., A2) than under more mild scenarios (e.g., B2), as confirmed by Table 1 .
Table 2 Annual yield growth rates $(\%)$ of rice, wheat, and maize in China under SRES A2 and $\mathrm{B} 2$

\begin{tabular}{lccccccc}
\hline Crop & \multicolumn{1}{l}{ SRES A2 } & & & \multicolumn{2}{l}{ SRES B2 } \\
\cline { 2 - 3 } \cline { 7 - 8 } & $1975-2015$ & $2015-2025$ & $2025-2035$ & & $1975-2015$ & $2015-2025$ & $2025-2035$ \\
\hline Rice & +1.01 & +0.15 & +0.38 & & +0.99 & +0.52 & -0.14 \\
Wheat & -0.14 & -0.14 & +0.55 & & +0.00 & -0.22 & +0.14 \\
Maize & +0.15 & +0.33 & +0.24 & & +0.20 & +0.54 & -0.05 \\
\hline
\end{tabular}


Table 3 Crop yield and food production capacity under the considered socio-economic and agronomic scenarios in association with the SRES A2 and B2 emission scenarios to explicitly show the effect of technology development on crop yield and production capacity

Numbers inside parenthesis are percent increase against the baseline values

\begin{tabular}{|c|c|c|c|c|c|c|c|c|}
\hline \multirow[t]{2}{*}{ Year } & \multicolumn{4}{|c|}{ No technology development } & \multicolumn{4}{|c|}{ Technology development } \\
\hline & $\begin{array}{l}\text { Rice } \\
\left(\mathrm{t} \mathrm{ha}^{-1}\right)\end{array}$ & $\begin{array}{l}\text { Wheat } \\
\left(\mathrm{t} \mathrm{ha}^{-1}\right)\end{array}$ & $\begin{array}{l}\text { Maize } \\
\left(\mathrm{t} \mathrm{ha}^{-1}\right)\end{array}$ & $\begin{array}{l}\text { Production } \\
\text { (million } t)\end{array}$ & $\begin{array}{l}\text { Rice } \\
\left(\mathrm{t} \mathrm{ha}^{-1}\right)\end{array}$ & $\begin{array}{l}\text { Wheat } \\
\left(\mathrm{t} \mathrm{ha}^{-1}\right)\end{array}$ & $\begin{array}{l}\text { Maize } \\
\left(\mathrm{t} \mathrm{ha}^{-1}\right)\end{array}$ & $\begin{array}{l}\text { Production } \\
\text { (million } \mathrm{t})\end{array}$ \\
\hline \multicolumn{9}{|c|}{ Baseline } \\
\hline 2009 & 6.6 & 4.7 & 5.3 & 531 & 6.6 & 4.7 & 5.3 & 531 \\
\hline \multicolumn{9}{|c|}{ SRES A2 } \\
\hline 2020 & $7.0(6)$ & $4.7(0)$ & $5.4(2)$ & $529(0)$ & $7.3(11)$ & $4.9(4)$ & $5.6(6)$ & $549(3)$ \\
\hline 2030 & $7.2(9)$ & $4.8(2)$ & $5.5(4)$ & $551(4)$ & $7.5(14)$ & $4.9(4)$ & $5.8(9)$ & $572(8)$ \\
\hline 2040 & $7.5(14)$ & $5.0(6)$ & $5.7(8)$ & $584(10)$ & $7.7(17)$ & $5.1(9)$ & $5.8(9)$ & $598(13)$ \\
\hline 2050 & $7.8(18)$ & $5.3(13)$ & $5.8(9)$ & $621(17)$ & $8.0(21)$ & $5.4(15)$ & $6.0(13)$ & $635(20)$ \\
\hline \multicolumn{9}{|c|}{ SRES B2 } \\
\hline 2020 & $7.2(9)$ & $4.7(0)$ & $5.5(4)$ & $540(2)$ & $7.7(17)$ & $5.1(9)$ & $5.9(11)$ & $584(10)$ \\
\hline 2030 & $7.3(11)$ & $4.7(0)$ & $5.6(6)$ & $569(7)$ & $7.9(20)$ & $5.1(9)$ & $6.1(15)$ & $615(16)$ \\
\hline 2040 & $7.2(9)$ & $4.9(4)$ & $5.6(6)$ & $592(11)$ & 7.5 (14) & $5.2(11)$ & $5.8(9)$ & $620(17)$ \\
\hline 2050 & $7.1(8)$ & $5.1(9)$ & $5.5(4)$ & $617(16)$ & $7.4(12)$ & $5.4(15)$ & $5.8(9)$ & $646(22)$ \\
\hline
\end{tabular}

\subsection{Yield}

In order to isolate the effect of climate change and to maintain comparability, the yields of rice, wheat and maize during the projection period of 2011-2040 were evaluated by applying the annual yield growth rate on the census yield in the baseline year of 2009 (NBSC 2010). The yields during 2041-2050 were extrapolated from the projected yields in 2040, assuming the same yield growth rate during 2041-2050 as during 2031-2040. The projected yields were then aggregated to the national scale and averaged at the decadal time scale and given in Table 3.

Climate change is simulated to have moderate positive effects on the yields of major food crops in China at the decadal time scale from 2020 through 2050 (Table 3, no technology). The maize yield, for instance, is projected to increase by $\sim 10 \%$, from $5.3 \mathrm{tha}^{-1}$ in 2009 to $5.8 \mathrm{tha}^{-1}$ in 2050 , under the A2 scenario. Under the B2 scenario, a $4 \%$ increase in maize yield is projected. Overall, crop yields are projected to increase in 21 out of 24 cases ( 3 crops by 4 decadal intervals by 2 scenarios, Table 3 , no technology). The wheat yield is projected to be mostly stagnated or decrease by a small margin under either A2 or B2. The average yield of all food crops taken together (i.e., staple grains plus tubers and beans; the proportion of tubers and beans in total food production, $10 \%$ in 2009, was assumed constant throughout the projection period) is projected to increase by $11 \%$ from $4.9 \mathrm{t} \mathrm{ha}^{-1}$ in 2009 to $5.4 \mathrm{t} \mathrm{ha}^{-1}$ in 2050 under A2, assuming that the sown area proportions of individual crops in 2009 are kept unchanged during the entire projection period, while this yield increase is projected to be $4 \%$ under B2, meaning that short-to-mediumterm yield growth is more likely to be achieved under the A2 scenario which assumes higher emission levels (320\% more $\mathrm{CO}_{2}$ in 2100 than in 2000), as also observed by others (e.g., Parry et al. 2005). Agricultural production will likely benefit from a more balanced development pathway as assumed under B2, but this benefit may probably only be achieved over longer terms.

\subsection{Food production capacities}

China's food production capacity (Table 3, with technology development) tends to increase over the projection period under both A2 and B2 scenarios. China will be able to achieve a production of 572 and 635 million tons (MT) from food crops under the A2, while this production is 615 and $646 \mathrm{MT}$ under the B2 scenarios, in 2030 and 2050, respectively, compared to the production of $531 \mathrm{MT}$ in 2009. It is clear that this increase in food production capacity is overwhelmingly attributed to production intensification as indicated by a $30 \%$ increase in the multi-cropping index values during 20092050 , especially under the B2 scenario (Table 3 ). The moderate positive effect of climate change on food yield (Tables 2 and 3) will not be able to offset the negative effect of the loss of cropland on food production in China over the projection period. China would only be able to achieve a production of 497 MT in 2050 under the B2 scenario, i.e., a $7 \%$ drop from the 2009 level, should the multi-cropping index value be kept at the same level as in 2009 , while this production would be $550 \mathrm{MT}$ in 2050 under A2, meaning a $4 \%$ increase over the baseline level. This mild increase in total food supply is insufficient to feed $17 \%$ more people (Table 1). As a result, per capita supply would drop from $\sim 400 \mathrm{~kg}$ to $\sim 350 \mathrm{~kg}$ under either A2 or B2 scenario. This shows that agricultural intensification will be the inevitable choice for countries like China to ensure food security over the long run (Godfray et al. 2011; Tilman et al. 2002). 


\subsection{Food security analysis}

The food security index (FSI) values in China, evaluated from a food supply-demand point of view (Ye and Van Ranst 2009) using census and estimated data for the pre2009 and model simulated crop yields under socioeconomic and agronomic scenarios in association with the SRES A2 and B2 climate change scenarios, are shown in Fig. 3. Historical variations in food security are well captured by the FSI curve. China's food security status was significantly improved soon after the long-lasting wars that ended in the late 1940s. At the end of the first 5-year plan, the FSI increased from -2.4 in 1949 to 31.4 in 1957 , showing that the supply-demand relationship turned from a $2.4 \%$ deficit to a $31.4 \%$ surplus. The peak FSI value of 38.5 appeared in 1984, coinciding with the record harvest of 390 MT in the same year. Although higher productions ( $\sim 500$ MT) were achieved consecutively during 19961999, the FSI values in the same period were not higher than that of 1984, reflecting the combined effects of a larger population and a higher standard of living. Extreme climatic events and natural hazards, which caused notable production losses during 2000-2003, were responsible for the second largest drop in the FSI values after the period of the Great Leap Forward (1957-1961). China has achieved record harvests for six consecutive years since 2004, reaching the level of 530 million tons in 2009. However, the average FSI level of 18.8 during the first decade of the twenty-first century is considerably lower than the average level of 31.9 in 1990s or 26.3 in 1980s, showing the dragging effect of steadily increasing consumption levels on FSI. This suggests that food utilization (safe, balanced and nutritious food, etc.; see Schmidhuber and Tubiello 2007) is gaining momentum and attention is needed on how to integrate it into existing food security assessment frameworks (e.g., Fig. 1) which took food availability as the primary indicator.

Statistical analysis was conducted to reveal the causeeffect relationship between crop yield and the FSI (Fig. 4). Results show that the correlation between crop yield and FSI is much weaker than the correlation between the yearto-year changes of the crop yield and the FSI. Only $22 \%$ of the variations in the absolute values of the FSI can be explained by the variations in the average yield of all food crops taken together, or $R^{2}=0.22(p<0.001)$, as shown in Fig. $4 \mathrm{c}$. However, as much as $82 \%$ of the variations in the year-to-year changes of the FSI values can be explained by the variations in the annual growth rate of the crop yield (Fig. 4f). It is important to note that the year-to-year changes of FSI, given by the first difference of the FSI series as inspired by the approach of Lobell and Field (2008) in relating $\mathrm{CO}_{2}$ growth rate to crop yield annual changes, is measured in terms of percent change of relative food surplus by definition, which is essentially the growth rate of the relative food surplus. The statistical results suggest that the annual growth rate of crop yield is a much better indicator of food security than crop yield per se, meaning that yield improvement on the yearly basis has great significance in ensuring food security for countries with a growing population, as in the case of China during the pre-2025 or pre-2040 era, depending on the choice population growth pathways associated with the B2 or A2 climate change scenarios, respectively (Table 1).

The Chinese population is projected to plateau and decrease within the course of the projection period, despite the difference on exact timing (Table 1). The FSI is predicted to drop sharply from 24.2 in 2009 to 10.2 and -4.5 in 2030 under the B2 and A2 scenarios, respectively (Fig. 3). This drop can be explained by the relative importance of population versus other, yield enhancement factors. Under the A2
Fig. 3 Relative food surplus (\%) in per capita terms, or the food security index (FSI), as evaluated using census data during 1949-2009 and as projected in 2030 and 2050. Horizontal bars represent the average FSI levels at the decadal time scale

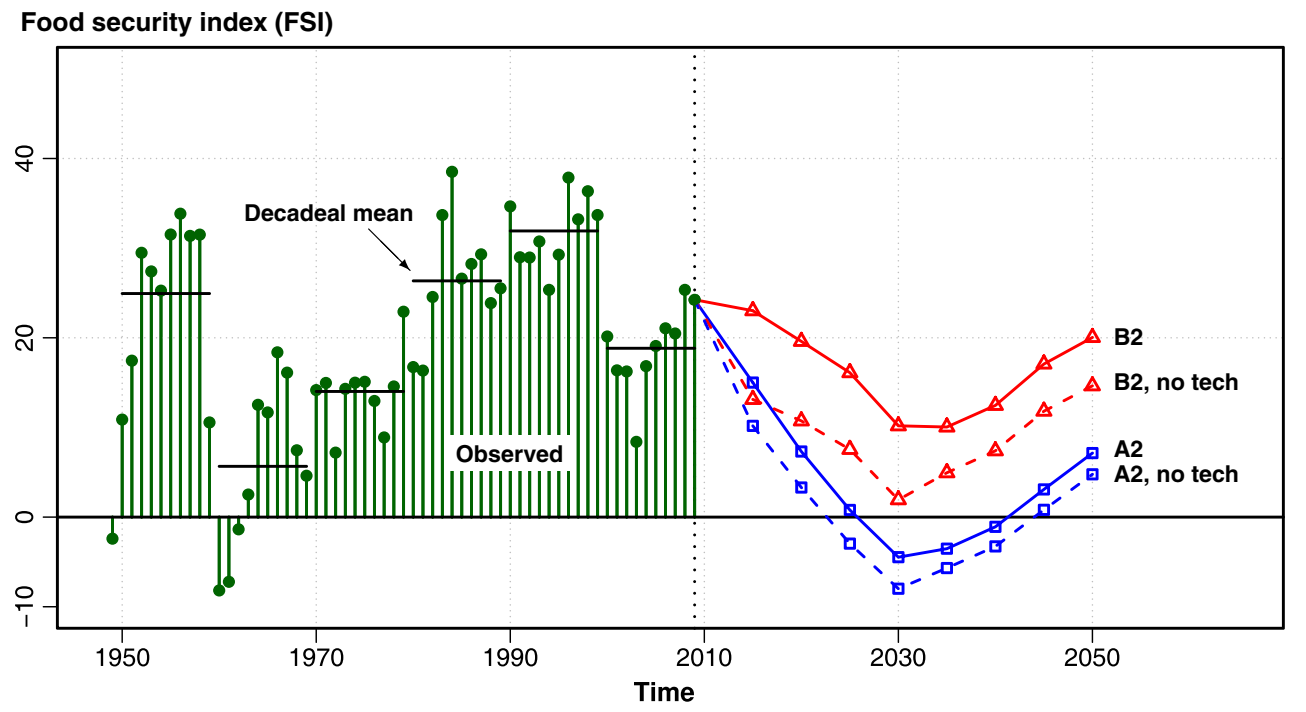


Fig. 4 Cause-effect relationships between crop yield and the food security index (FSI) values show that yield growth rate is a better indicator of food security than absolute yield. a Time plot of FSI; b time plot of average yield of food crops; c scatter plot of FSI versus yield, overlaid with the trend line $\left(R^{2}=0.22\right)$; d time plot of the yield-to-year FSI changes ( $\triangle \mathrm{FSI})$, evaluated as the first difference (Lobell and Field 2008) of the FSI series; e time plot of the annual growth rate of the average yield of food crops ( $\Delta$ Yield), evaluated as the ratio $(\%)$ between the first difference of yield and absolute yield; $\mathbf{f}$ scatter plot of $\Delta$ FSI versus $\Delta$ Yield $\left(R^{2}=0.82\right)$
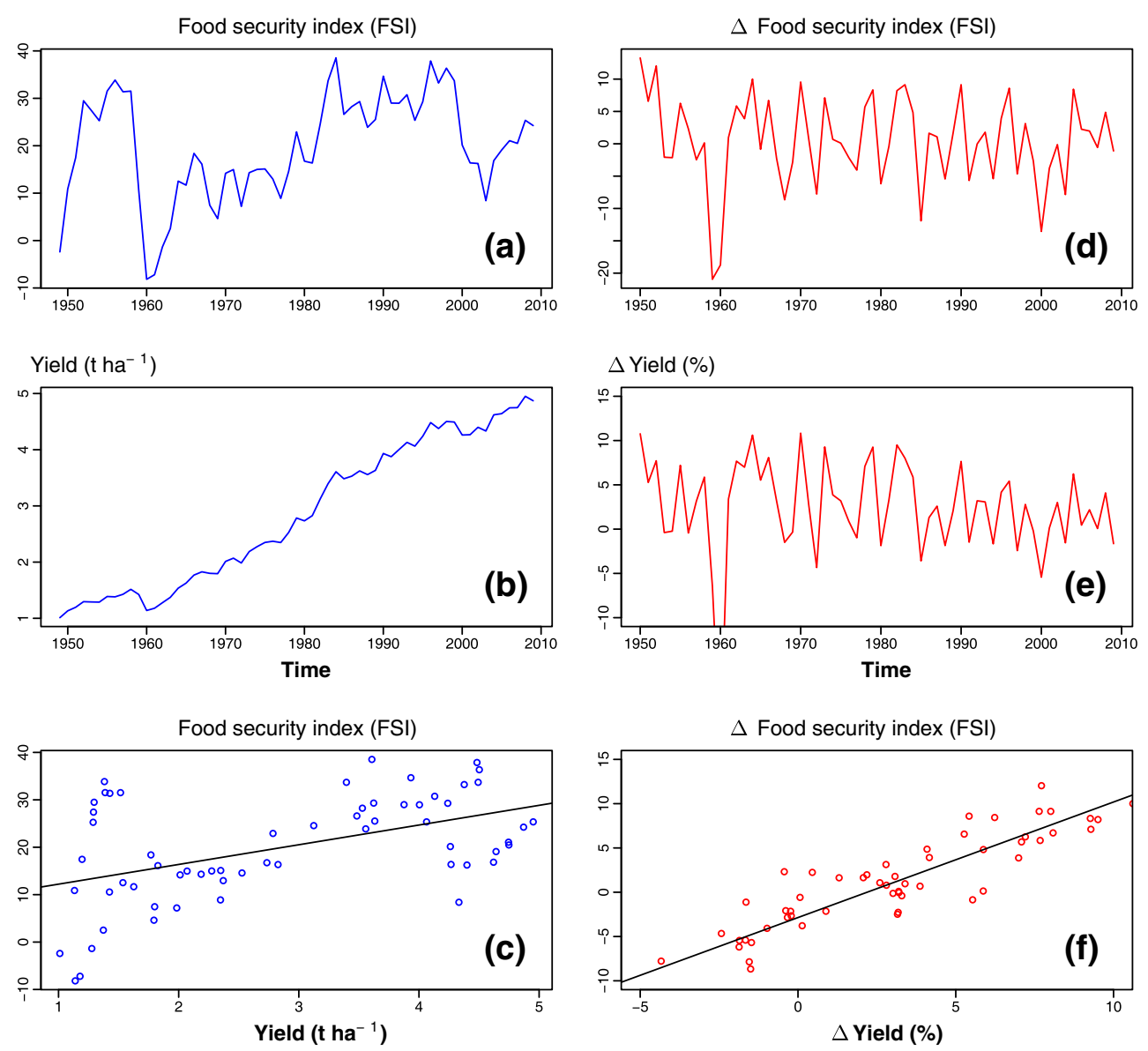

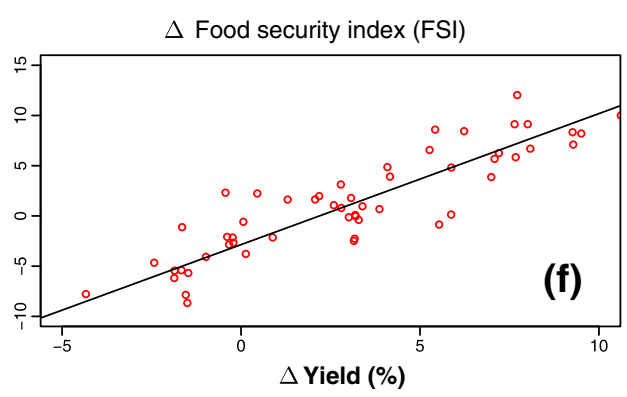

scenario, population grows quickly by a margin of 240 million people during 2009-2030, which is equivalent to the population size of Indonesia as the fourth most populous country of the world. Alongside the high population growth, the socio-economic and agronomic development takes a sub-optimal pathway. The multi-cropping index, for example, increases by 9 units from $130 \%$ in 2009 to $139 \%$ in 2030. Due to the input limitations, only half of the available higher-yielding crop varieties can be adopted and crop management can only be exercised half efficiently as compared to the B2 scenario. Aggregate, technology development will result in a $0.75 \%$ yield enhancement effect annually. Consequently, average crop yield will increase by $7 \%$ in 2030 as compared to 2009 with the yield effect of climate change included. Despite all these minor positive effects, per capita supply decreases all the way down from $398 \mathrm{~kg}$ in 2009 to $363 \mathrm{~kg}$ in 2030 . In contrast, per capita consumption increases steadily from $337 \mathrm{~kg}$ in 2009 to $400 \mathrm{~kg}$ in 2030 (not shown). This shows that population growth has enormous impact on food security (Hopfenberg and Pimentel 2001). During the period of 2030-2050, the FSI is predicted to increase from -4.5 in 2030 to 7.1 in 2050 under the A2 and from 10.2 to 20.0 under the B2 scenario, respectively, coinciding with the projected decrease in population size during the period (Table 1), reaffirming the controlling effect of population growth on food security in populous countries like China. Therefore, as a countermeasure for food security, the yield growth rate should be maintained at a level higher than that of population growth. Hopfenberg and Pimentel (2001) argued with their analysis that crop yield needs to grow 1-2\% faster than population growth rate in order to secure food supply. Alternatively, population control should be prioritized where proper yield growth rate cannot be sustained (Ehrlich and Ehrlich 2009).

A comparison between the simulated FSI curves under the A2 and B2 associated scenarios shows that the socioeconomic and agronomic pathways in association with the A2 and B2 emission scenarios have significant impact on FSI. The average distance between these two curves during 2011-2050 is evaluated to be 13 units, meaning that food surplus linked with a more balanced development pathway (B2, low population growth, stimulation of technological change and emphasis on environmental sustainability) is $13 \%$ higher than a more stagnated pathway (A2, high population growth, low economic development, low regional coordination). This difference can translate into 76 million tons of additional grain harvests in 2030 under B2. The average distance between the simulated FSI curve under B2, 
for example, and the FSI curve under B2 but excluding technology development during 2011-2050 is evaluated to be 7 units (Fig. 3). This reveals that yield improvements realized by technology development alone may have raised the food surplus level during 2011-2050 under B2 by $7 \%$, suggesting that technology development is one critical means to raise food security level through yield growth rate maintenance (Alston et al. 2009).

\subsection{Policy options}

We advise the following research priorities and policy reforms in order to ensure food security under climate change: (1) Modeling. The food system is complex, and interventions often have unintended and detrimental effects on food security. There is a clear need to bring together economists and scientists in modeling the food system (Godfray et al. 2011). Biophysical-economic models using food price (Alston et al. 2009) as the coupling parameter are one of the priorities that have the potential to meet the needs of agro-environmental to socio-economic decision makings. Multi-model ensemble simulation of crop yield under climate change (Challinor et al. 2009; Gosling et al. 2011) is much needed to control and to quantify the uncertainties linked with the obtained results. Coordinated use of these models will hopefully provide a promising platform for food security assessment (Rötter et al. 2011); (2) Technology. Past experiences show that breeding and agronomic improvements have on average achieved a linear increase in global food production at an average rate of 32 million tons per year for the past few decades. Contemporary, large-scale environmental change poses great threats to the continuity of this linear trend, but it is not prohibiting. Internationally coordinated efforts are in urgent need to speed up the breeding of new crop varieties which are more efficient in utilizing water (Molden and Sakthivadivel 1999) and nitrogen fertilizers (Jin 2011), and drought and heat tolerant (Challinor et al. 2010; Long 2012); (3) Extension. In most circumstances in China, extension services are the key to swift and effective implementation of new technologies. However, the extension service network needs to be reinvented to build the relevant skills base among food producers, and better economic incentives need to be introduced to make it worthwhile for farmers to adopt new technologies and/or practices. The extension services need to be revitalized to guarantee the successful adoption of such technologies into the smallholder systems in China's food production (Piao et al. 2010).

\section{Conclusions}

An integrated assessment of food security in China based on the simulated effects of climate change on crop yield in 2050 was presented in this paper. The assessment involved a range of socio-economic and agronomic scenarios which were developed following two contrasting development pathways associated with the IPCC SRES A2 and B2 climate change scenarios. The food security index (FSI, or relative food surplus per capita) was found to be a simple yet powerful and robust tool in quantitative cause-effect food security analysis. The obtained results showed that climate change only has a moderate positive effect on food security as compared to other factors like cropland area and population growth. Overall, the socio-economic development pathways exert great impact on the future trends of food security. Particularly, the more balanced development pathway with emphasis on environmental sustainability in association with the B2 emission scenario was found much superior in ensuring food security than the other A2associated pathway. Using regression analysis that correlates FSI and crop yield, we found that yield growth rate is a much better indicator of food security than crop yield per se, meaning that yield improvement on the yearly basis has great significance in ensuring food security for countries with a growing population like China. The relatively lower than expected FSI values during the first decade of the twenty-first century suggested that per capita food consumption in China is undergone a steady growth. Here we argue that the gravity center of food security in China starts shifting from the availability aspects to the utilization aspects. More attention is therefore needed on food safety and balanced nutrition issues in order to ensure food security in China over the long run.

Acknowledgments The research was supported by the National Basic Research Program of China (2010CB951504). Partial supports also came from the Ministry of Science and Technology of China (2010DFB10030) and the National Natural Science Foundation of China (41001246). The authors thank the Flemish Interuniversity Council (VLIR-UOS NBTP2011-67885) of Belgium for supporting the writing of this paper.

Open Access This article is distributed under the terms of the Creative Commons Attribution License which permits any use, distribution, and reproduction in any medium, provided the original author(s) and the source are credited.

\section{References}

Alston JM, Beddow JM, Pardey PG (2009) Agricultural research, productivity, and food prices in the long run. Science 325:12091210. doi:10.1126/science. 1170451

Challinor AJ, Wheeler T, Hemming D, Upadhyaya HD (2009) Ensemble yield simulations: crop and climate uncertainties, sensitivity to 
temperature and genotypic adaptation to climate change. Clim Res 38:117-127. doi:10.3354/cr00779

Challinor AJ, Simelton ES, Fraser EDG, Hemming D, Collins M (2010) Increased crop failure due to climate change: assessing adaptation options using models and socio-economic data for wheat in China. Environ Res Lett 5:034012. doi:10.1088/1748-9326/5/3/034012

Change GH, Brada FC (2006) The paradox of China's growing underurbanization. Econ Syst 30:24 40. doi:10.1016/j.ecosys.2005.07.002

Easterling WE, Chen X, Hays C, Brandle JR, Zhang H (1996) Improving the validation of model-simulated crop yield response to climate change: an application to the EPIC model. Clim Res 6:263-273. doi:10.3354/cr0006263

Ehrlich PR, Ehrlich AH (2009) The population bomb revisited. Electron J Sust Dev 1:63-71

Godfray HCJ, Pretty J, Thomas SM, Warham EJ, Beddington JR (2011) Linking policy on climate and food. Science 331:10131014. doi:10.1126/science. 1202899

Gosling SN, Warren R, Arnell NW, Good P, Caesar J, Bernie D, Lowe JA, van der Linden P, O'Hanley JR, Smith SM (2011) A review of recent developments in climate change science. Part II: the globalscale impacts of climate change. Progr Phys Geogr 35:443-464. doi: $10.1177 / 0309133311407650$

Guo JH, Liu XJ, Zhang Y, Shen JL, Han WX, Zhang WF, Christie P, Goulding KWT, Vitousek PM, Zhang FS (2010) Significant acidification in major Chinese croplands. Science 327:1008-1010. doi:10.1126/science. 1182570

Hansen J, Sato M, Ruedy R, Lo K, Lea DW, Medina-Elizade M (2006) Global temperature change. Proc Natl Acad Sci USA 103:1428814293. doi:10.1073/pnas.0606291103

Hopfenberg R, Pimentel D (2001) Human population numbers as a function of food supply. Environ Dev Sustain 3:1-5. doi:10.1023/ A:1011463231976

Jiang T (2008) WTO accession and food security in China. In: Chen C, Duncam R (eds) Agriculture and food security in China. The Australian National University E Press and Asia Pacific Press, Canberra, pp 183-202

Jin J (2011) Changes in the efficiency of fertilizer use in China. J Sci Food Agric 92:1002-1009. doi:10.1002/jsfa.4700

Jones JW, Hoogenboom G, Porter CH, Boote KJ, Batchelor WD, Hunt LA, Wilkens PW, Singh U, Gijsman AJ, Ritchie JT (2003) The DSSAT cropping system model. Eur J Agron 18:235-265. doi:10.1016/S1161-0301(02)00107-7

Knox JW, Matthews RB, Wassmann R (2000) Using a crop/soil simulation model and GIS techniques to assess methane emissions from rice fields in Asia. III. Database. Nutr Cycl Agroecosyst 58:179-199. doi:10.1023/A:1009898720354

Kotir JH (2011) Climate change and variability in Sub-Saharan Africa: a review of current and future trends and impacts on agriculture and food security. Environ Dev Sustain 13:587-605. doi:10.1007/ s10668-010-9278-0

Li W, Takahashi T, Suzuki N, Kaiser HM (2011) The impact of climate change on maize yield in the United States and China. Agr Syst 104:348-353

Lin E, Xiong W, Ju H, Xu Y, Li Y, Bai L, Xie L (2005) Climate change impacts on crop yield and quality with $\mathrm{CO}_{2}$ fertilization in China. Phil Trans R Soc B 360:2149-2154. doi:10.1098/rstb.2005.1743

Lobell DB, Field CB (2007) Global scale climate-crop yield relationships and the impacts of recent warming. Environ Res Lett 2:014002. doi:10.1088/1748-9326/2/1/014002

Lobell DB, Field CB (2008) Estimation of the carbon dioxide $\left(\mathrm{CO}_{2}\right)$ fertilization effect using growth rate anomalies of $\mathrm{CO}_{2}$ and crop yields since 1961. Glob Chang Biol 14:39-45. doi:10.1111/ j.1365-2486.2007.01476.x

Lobell DB, Burke MB, Tebaldi C, Mastrandrea MD, Falcon WP, Naylor RL (2008) Prioritizing climate change adaptation needs for food security in 2030. Science 319:607-610. doi:10.1126/ science. 1152339

Long SP (2012) Virtual Special Issue on food security - greater than anticipated impacts of near-term global atmospheric change on rice and wheat. Glob Chang Biol 18:1489-1490. doi:10.1111/ j.1365-2486.2012.02676.x

Long SP, Ainsworth EA, Leakey ADB, Nösberger J, Ort DR (2006) Lower-than-expected crop yield stimulation with rising $\mathrm{CO} 2$ concentrations. Science 312:1918-1921. doi:10.1126/science.1114722

Molden D, Sakthivadivel R (1999) Water accounting to assess use and productivity of water. Int J Water Resour Dev 15:55-71. doi:10.1080/07900629948934

NBSC (National Bureau of Statistics of China) (2010) Statistical yearbook of China 2010. China Statistical Press, Beijing (in Chinese)

NOARP (National Office of Agricultural Regional Planning) (1997) China agricultural resource planning and development strategies. Meteorological Press, Beijing (in Chinese)

Parry ML, Rosenzweig C, Iglesias A, Livermore M, Fischer G (2004) Effects of climate change on global food production under SRES emissions and socio-economic scenarios. Glob Environ Chang 14:53-67. doi:10.1016/j.gloenvcha.2003.10.008

Parry M, Rosenzweig C, Livermore M (2005) Climate change, global food supply and risk of hunger. Phil Trans R Soc B 360:21252138. doi:10.1098/rstb.2005.1751

Pawls WJ, Brakensiek DL, Saxton KE (1982) Estimation of soil water properties. Trans ASAE 25:1316-1320, 1328

Piao S, Ciais P, Huang Y, Shen Z, Peng S, Li J, Zhou L, Liu H, Ma Y, Ding Y, Friedlingstein P, Liu C, Tan K, Yu Y, Zhang T, Fang J (2010) The impacts of climate change on water resources and agriculture in China. Nature 467:43-51. doi:10.1038/nature09364

Pohlert T (2004) Use of empirical global radiation models for maize growth simulation. Agric For Meteorol 126:47-58. doi:10.1016/ j.agrformet.2004.05.003

Portmann FT, Siebert S, Döll P (2010) MIRCA2000-global monthly irrigated and rainfed crop areas around the year 2000: a new high-resolution data set for agricultural and hydrological modeling. Glob Biogeochem Cycles 24: GB1011. doi:10.1029/2008GB003435

Rötter RP, Carter TR, Olesen JE, Porter JR (2011) Crop-climate models need an overhaul. Nature Climate Change 1:175-177. doi: $10.1038 /$ nclimate 1152

Schmidhuber J, Tubiello FN (2007) Global food security under climate change. Proc Natl Acad Sci USA 104:19703-19708. doi:10.1073/ pnas.0701976104

Steltzer H, Post E (2009) Seasons and life cycles. Science 324:886887. doi:10.1126/science. 1171542

Tester M, Langridge P (2010) Breeding technologies to increase crop production in a changing world. Science 327:818-822. doi:10.1126/science. 1183700

Tilman D, Cassman KG, Matson PA, Naylor R, Polasky R (2002) Agricultural sustainability and intensive production practices. Nature 418:671-677. doi:10.1038/nature01014

Tubiello FN, Soussana J-F, Howden SM (2007) Crop and pasture response to climate change. Proc Natl Acad Sci USA 104:19686-19690. doi:10.1073/pnas.0701728104

Turral H, Burke J, Faurès J-M (2011) Climate change, water and food security. FAO Water Reports 36. FAO, Rome

UNFPA (United Nations Population Fund) (2010) State of the world population 2010. UNFPA, New York

Wu W, Tang H, Yang P, You L, Zhou Q, Chen Z, Shibasaki R (2011) Scenario-based assessment of future food security. J Geogr Sci 21:3-17. doi:10.1007/s11442-011-0825-x

Xiong W, Matthews R, Holman I, Lin E (2007) Modelling China's potential maize production at regional scale under climate change. Clim Chang 85:433-451. doi:10.1007/s10584007-9284-x 
Xiong W, Conway D, Holman I, Lin E (2008a) Evaluation of CERESwheat simulation of wheat production in China. Agron $\mathrm{J}$ 100:1720-1728. doi:10.2134/agronj2008.0081

Xiong W, Holman I, Conway D, Lin E, Li Y (2008b) A crop model cross calibration for use in regional climate impacts studies. Ecol Model 213:365-380. doi:10.1016/j.ecolmodel.2008.01.005

Xu YL, Zhang Y, Lin ED, Wan T, Dong WJ, Jones R, Hassell D, Wilson S (2006) Analyses on the climate change responses over China under SRES B2 scenario using PRECIS. Chin Sci Bull 51:2260-2267. doi:10.1007/s11434-006-2099-8
Ye L, Van Ranst E (2009) Production scenarios and the effect of soil degradation on long-term food security in China. Glob Environ Chang 19:464-481. doi:10.1016/j.gloenvcha.2009.06.002

Ye L, Tang H, Zhu J, Verdoodt A, Van Ranst E (2008) Spatial patterns and effects of soil organic carbon on grain productivity assessment in China. Soil Use Manag 24:80-91. doi:10.1111/j.14752743.2007.00136.x

Zhao J, Luo Q, Deng H, Yan Y (2008) Opportunities and challenges of sustainable agricultural development in China. Phil Trans R Soc B 363:893-904. doi:10.1098/rstb.2007.2190 